Article

\title{
Removing Sr(II) and Cs(I) from the Aqueous Phase Using Basil Seed and Elucidating the Adsorption Mechanism
}

\author{
Yugo Uematsu ${ }^{1}$, Fumihiko Ogata ${ }^{1}{ }^{(}$, Chalermpong Saenjum ${ }^{2,3}{ }^{(0}$, Takehiro Nakamura ${ }^{1}$ and \\ Naohito Kawasaki 1,4,*(D) \\ 1 Faculty of Pharmacy, Kindai University, 3-4-1 Kowakae, Higashi-Osaka, Osaka 577-8502, Japan; \\ y.u.pharmafocus@gmail.com (Y.U.); ogata@phar.kindai.ac.jp (F.O.); nakamura@phar.kindai.ac.jp (T.N.) \\ 2 Faculty of Pharmacy, Chiang Mai University, Suthep Road, Muang District, Chiang Mai 50200, Thailand; \\ chalermpong.saenjum@gmail.com \\ 3 Cluster of Excellence on Biodiversity-based Economics and Society (B.BES-CMU), Chiang Mai University, \\ Suthep Road, Muang District, Chiang Mai 50200, Thailand \\ 4 Antiaging Center, Kindai University, 3-4-1 Kowakae, Higashi-Osaka, Osaka 577-8502, Japan \\ * Correspondence: kawasaki@phar.kindai.ac.jp; Tel.: +81-6-4307-4012
}

Received: 13 February 2020; Accepted: 2 April 2020; Published: 5 April 2020

\begin{abstract}
To confirm the capability and mechanisms of $\operatorname{Sr}(\mathrm{II})$ and $\mathrm{Cs}(\mathrm{I})$ adsorption from the aqueous phase using basil seed (BS), virgin BS, calcined BS (BS500 and BS1000), and enzymatically treated BS, namely Mannanase BGM (M-BS), Pectinase G (P-BS), Hemicellulase (H-BS), and Cellulase A (C-BS) was evaluated. The adsorption capabilities of $\mathrm{Sr}(\mathrm{II})$ and $\mathrm{Cs}(\mathrm{I})$ of various BS adsorbents were also evaluated. The quantity of $\mathrm{Sr}(\mathrm{II})$ and $\mathrm{Cs}(\mathrm{I})$ adsorbed onto BS was greater than that of BS500 or BS1000, suggesting that the physicochemical characteristics of the BS surface affected Sr(II) and Cs(I) removal from the aqueous phase. Furthermore, the quantity of $\mathrm{Sr}(\mathrm{II})$ and $\mathrm{Cs}(\mathrm{I})$ adsorbed onto virgin BS was greater than that of enzymatically treated BS, indicating that glucomannan or $(1,4)$-xylan in the cellulosic hydrocolloid of the BS strongly affected the adsorption capability of Cs(I) or Sr(II) (except for M-BS in Sr(II) adsorption). Our obtained results indicate that, as an adsorbent, BS was capable of removing $\operatorname{Sr}(\mathrm{II})$ and $\mathrm{Cs}(\mathrm{I})$ from the aqueous solution.
\end{abstract}

Keywords: basil seed; hydrocolloid; strontium ion; cesium ion; adsorption

\section{Introduction}

The nuclear industry emerged around 1940, and humans have benefited in various ways from nuclear technologies. However, nuclear power plants have received increasing attention owing to their high-risk potential to human health and the ecosystem in recent years [1]. Particularly, the Fukushima Daiichi Nuclear Power Station in Japan (2001) and the Chernobyl Nuclear Power Plant in the Ukrainian SSR (1986) were the sites of well-known disasters [2]. Therefore, the use and subsequent disposal of radioactive waste or the release of these radioactive materials into the water environment is a major concern for the nuclear field [3]. Strontium ( $\mathrm{Sr}(\mathrm{II}))$ and cesium $(\mathrm{Cs}(\mathrm{I}))$ are fission products of nuclear fuels contained in radioactive waste. Because of their long half-life (Sr: 28.74 years, Cs: 30.04 years) and toxicity (such as their carcinogenic properties), technology for removing or separating these materials from water requires special attention [4-7].

Various studies have reported the production of low-cost adsorbents prepared from waste biomass for $\operatorname{Sr}(\mathrm{II})$ and $\mathrm{Cs}(\mathrm{I})$ removal from the aqueous phase [3,8-11]. These reported technologies were based on an adsorption process using biomass adsorbents, indicating that the adsorption process using biomass is an effective and economically promising technique for $\mathrm{Sr}(\mathrm{II})$ and $\mathrm{Cs}(\mathrm{I})$ removal from water. Additionally, microorganisms including Bacillus spp., Pectinatella magnifica, and Pseudomonas spp. 
etc. have also proven to be useful in $\mathrm{Sr}(\mathrm{II})$ and Cs(I) removal from the aqueous phase. However, in these methods, microorganisms are required to immobilize on a carrier, such as ceramic $[12,13]$. Our previous studies also reported on the capability of Sr(II) and Cs(I) removal from the aqueous phase using disposed human hair or waste biomass tapioca [14,15].

In this study, basil (Ocimum basilicum) was used for $\mathrm{Sr}(\mathrm{II})$ and $\mathrm{Cs}(\mathrm{I})$ removal from the water environment. Basil is an herb or spice that is cultivated in regions worldwide, especially in Southeast Asia. In Thailand, the Department of Agriculture, Ministry of Agriculture and Cooperatives reported that the total productivity of basil seed was 280 tons in 2015, while basil straws were produced as byproducts. Additionally, basil seeds are widely consumed as a health dessert [16] and they also have medicinal values such as antispasmodic and stomachic properties $[17,18]$. However, all basil seeds are not effectively used or recycled in the current situation. Thus, if unused or unrecycled basil seed could be explored, its value and applicability could significantly increase. A previous study reported a cellulosic hydrocolloid system present in the seeds of plants (including basil seed (BS)) [19], and the mucilaginous seed showed that it had the capability to adsorb elements such as $\mathrm{Sr}, \mathrm{Cs}$, and $\mathrm{Cr}[3,20]$. The cellulosic hydrocolloid consists of numerous kinds of monosaccharides (namely D-glucose, D-galactose, D-mannose, and L-arabinose) and uronic acid, such as galacturonic acid and mannuronic acid. These saccharides are formed by two main fractions: glucomannan (43\%) and (1,4)-xylan (24\%) [19]. However, there is a lack of information regarding the relationship between the amount of $\mathrm{Sr}(\mathrm{II})$ and $\mathrm{Cs}(\mathrm{I})$ adsorbed and the properties of the BS (cellulosic hydrocolloid).

In a recent study, BS was used to adsorb Sr(II) and Cs(I) from an aqueous solution, and the characteristics of calcination or enzymatically treated BS were investigated. In addition, the changes in physicochemical properties (the mucilaginous and swell-upon-wetting nature) of seeds were assessed for calcination at 500 and $1000{ }^{\circ} \mathrm{C}$. Subsequently, the equilibrium adsorption, the effect of contact time and solution $\mathrm{pH}$ using BS biomass were demonstrated. The obtained results explained the adsorption mechanism of BS on Sr(II) and Cs(I) which can be used to resolve the water environment and waste biomass material issues.

\section{Materials and Methods}

\subsection{Materials}

Virgin BS was obtained from Thai Cereal World Co., Ltd. (Bangkok, Thailand). Calcined BS was prepared by carbonizing the BS in a muffle furnace at $500^{\circ} \mathrm{C}$ or $1000{ }^{\circ} \mathrm{C}$ for $2 \mathrm{~h}$ which was denoted as BS500 and BS1000, respectively. Mannanase BGM, pectinase G, hemicellulase, and cellulase A were purchased from Amano Enzyme Inc., Nagoya, Japan. The BS was treated with various enzymes by the following procedure. The BS and enzyme were mixed in the ratio of 1:1 in $500 \mathrm{~mL}$ Mcilvaine buffer $\mathrm{pH}$ 4.0-5.0. The optimum conditions of enzymatic treatment were obtained from Amano Enzyme Inc., Nagoya, Japan and are listed in Table 1. Subsequently, the reaction mixtures were stirred at $100 \mathrm{rpm}$ for at $45-70{ }^{\circ} \mathrm{C} 24 \mathrm{~h}$ and then filtered through a $0.45 \mu \mathrm{m}$ membrane filter. The obtained BS was freeze-dried at $80^{\circ} \mathrm{C}$. The treated BS samples with Mannanase BGM, pectinase $\mathrm{G}$, hemicellulase, and cellulase $\mathrm{A}$ are denoted as Mannanase BGM (M-BS), Pectinase G (P-BS), Hemicellulase (H-BS), and Cellulase A (C-BS), respectively.

Table 1. The conditions of enzyme treatment with basil seed (BS).

\begin{tabular}{cccc}
\hline Adsorbents & Enzyme & pH & Temperature $\left({ }^{\circ} \mathbf{C}\right)$ \\
\hline M-BS & Mannanase BGM & 5.0 & $50-70$ \\
P-BS & Pectinase G & 4.0 & 50 \\
H-BS & Hemicellulase & 4.5 & 45 \\
C-BS & Cellulase A & 4.5 & $50-60$ \\
\hline
\end{tabular}


Sr standard solution $\left(\mathrm{SrCO}_{3}\right.$ in $0.1 \mathrm{~mol} / \mathrm{L}$ nitric acid; $\left.1000 \mathrm{mg} / \mathrm{L}\right), \mathrm{Cs}$ standard solution $(\mathrm{CsCl}$ in water; $1000 \mathrm{mg} / \mathrm{L}$ ), sodium hydroxide, and hydrochloric acid were purchased from FUJIFILM Wako Pure Chemical Co. (Osaka, Japan).

The morphologies of the adsorbents were examined by scanning electron microscopy SU1510 (SEM, Hitachi High-Technologies Co., Tokyo, Japan). The specific surface area and pore volume were measured using a specific surface analyzer NOVA4200e (Quantachrome Instruments Japan G.K., Kanagawa, Japan). Elemental analysis was conducted using an electron probe microanalyzer JXA-8530F (EPMA, JEOL Ltd., Tokyo, Japan). The measurement conditions were as follows: accelerating voltage of $15.0 \mathrm{keV}$, probe current of $20 \mathrm{~mA}$, and a slot beam diameter. The thermogravimetry and differential thermal analysis were measured using a thermal gravimetric differential thermal analyzer TG8120 (TGA-DTA, Rigaku Co., Tokyo, Japan). The $\mathrm{pH}$ point of zero charge $\left(\mathrm{pH}_{\mathrm{pzc}}\right)$ and the surface functional groups of the adsorbents were measured by the Faria and Boehm titration methods, respectively [21,22].

\subsection{Adsorption Capability of Sr(II) And Cs(I) Using the BS, Calcined BS, And Enzyme-Treated BS}

A total of $0.05 \mathrm{~g}$ of adsorbents were mixed with $50 \mathrm{~mL}$ of Sr (II) or Cs (I) solutions at $1000 \mu \mathrm{g} / \mathrm{L}$. Then, the reaction mixtures were stirred at $100 \mathrm{rpm}$ at $25^{\circ} \mathrm{C}$ for $24 \mathrm{~h}$. After filtration through a $0.45 \mu \mathrm{m}$ membrane filter, the obtained filtrate was analyzed using inductively coupled plasma optical emission spectrometry iCAP 7600 Duo (ICP-OES, Thermo Fisher Scientific Inc., Kanagawa, Japan) or inductively coupled plasma mass spectrometry ICPM-8500 (ICP-MS, Shimadzu Co., Kyoto, Japan) for Sr(II) or $\mathrm{Cs}(\mathrm{I})$, respectively. The quantity of $\operatorname{Sr}(\mathrm{II})$ and $\mathrm{Cs}(\mathrm{I})$ ions adsorbed were calculated using the levels before and after adsorption in Equation (1).

$$
q=\frac{\left(C_{0}-C_{e}\right) V}{W}
$$

where $q$ is the quantity adsorbed $(\mu \mathrm{g} / \mathrm{g}), C_{0}$ is the initial concentration $(\mu \mathrm{g} / \mathrm{L}), C_{\mathrm{e}}$ is the equilibrium concentration $(\mu \mathrm{g} / \mathrm{L}), V$ is the solvent volume $(\mathrm{L})$ and $W$ is the weight of the adsorbent $(\mathrm{g})$.

\subsection{Adsorption Isotherms of Sr(II) And Cs(I) by the BS and Calcined BS}

A total of $0.05 \mathrm{~g}$ of adsorbents were mixed with $50 \mathrm{~mL}$ of $\mathrm{Sr}$ (II) or Cs (I) solution at 1-1000 $\mu \mathrm{g} / \mathrm{L}$, and then, the reaction mixtures were stirred at $100 \mathrm{rpm}$ at $25^{\circ} \mathrm{C}$ for $24 \mathrm{~h}$. The quantity adsorbed was calculated using Equation (1).

\subsection{Effects of Contact Time And pH on the Adsorption of Sr(II) And CS(I) by the BS and Calcined BS}

To investigate the effects of contact time, $0.05 \mathrm{~g}$ of adsorbents were mixed with $50 \mathrm{~mL}$ of Sr (II) or Cs (I) solution at $1000 \mu \mathrm{g} / \mathrm{L}$, and then, the reaction mixtures were stirred at $100 \mathrm{rpm}$ at $25^{\circ} \mathrm{C}$ for $0.5,1,3,6,16,20$, and $24 \mathrm{~h}$. To examine the effects of $\mathrm{pH}, 0.05 \mathrm{~g}$ adsorbents were mixed with $50 \mathrm{~mL}$ of $\mathrm{Sr}$ (II) or Cs (I) solution at $1000 \mu \mathrm{g} / \mathrm{L}$, the initial $\mathrm{pH}$ in the sample solution was adjusted from 2 to 12 using hydrochloric acid or sodium hydroxide solution. Then, the reaction mixtures were stirred at $100 \mathrm{rpm}$ at $25^{\circ} \mathrm{C}$ for $24 \mathrm{~h}$. The quantity of Sr(II) or Cs(I) adsorbed was calculated by Equation (1). The results in this study are expressed as means \pm standard errors ( $n=2-3$ (number of experiments), Sections 2.2-2.4).

\section{Results and Discussion}

\subsection{Effect of Calcination Treatment on Physicochemical Properties}

SEM images of virgin and calcined BSs are shown in Figure 1a. A structural collapse was observed, and the pores were increased with increasing calcination temperatures. Table 2 lists the physicochemical properties of BS, BS500, and BS1000. The surface functional groups decreased by the calcination treatment, indicating that the acidic or basic functional groups disappeared via carbonization. Similar changes to the surface functional groups with varying calcination temperatures were reported in a 
previous study [23]. Conversely, the $\mathrm{pH}_{\mathrm{pzc}}$ value elevated with increasing calcination temperatures. In addition, the specific surface areas of BS, BS500, and BS1000 were $0.265,0.937$, and $86.902 \mathrm{~m}^{2} / \mathrm{g}$, respectively. Therefore, the novel carbonaceous material (BS1000) was produced from the BS using the calcination treatment. Figure $1 \mathrm{~b}$ shows the TGA-DTA curves of the BS. TGA decreased and DTA increased between $300-600^{\circ} \mathrm{C}$. Yokoyama et. al. reported that the number of phenolic, carboxyl, and other functional groups decreased upon carbonization at approximately $600{ }^{\circ} \mathrm{C}$. Therefore, similar changes (combustion) occurred in our experiment [23]. Additionally, more than 150 species of common basil (Ocimum basilicum L.) genus have been recognized [24]. Therefore, the physicochemical characteristics differ more or less according to the cultivation condition, indicating that the obtained carbonaceous materials from basil seed at different calcination temperatures might affect the adsorption capability of $\mathrm{Sr}(\mathrm{II})$ and $\mathrm{Cs}(\mathrm{I})$ in the aqueous solution.
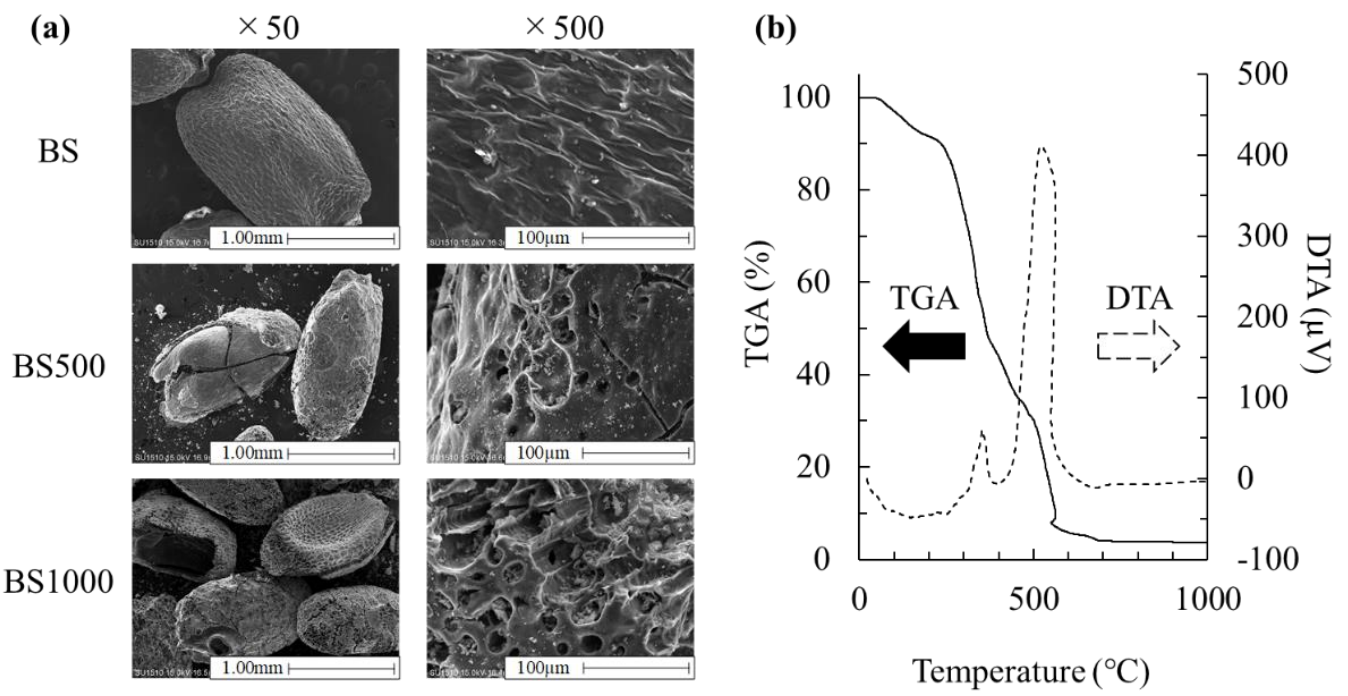

Figure 1. SEM images of adsorbents (a) and thermal gravimetric differential thermal analyzer (TGA-DTA) curves of BS (b).

Table 2. Physicochemical properties of adsorbents.

\begin{tabular}{|c|c|c|c|c|c|c|c|}
\hline \multirow{2}{*}{ Adsorbents } & \multirow{2}{*}{$\mathrm{pH}_{\mathrm{pzc}}$} & \multicolumn{2}{|c|}{$\begin{array}{l}\text { Surface Functional } \\
\text { Groups (mmol/g) }\end{array}$} & \multirow{2}{*}{$\begin{array}{c}\text { Specific Surface } \\
\text { Area }\left(\mathrm{m}^{2} / \mathrm{g}\right)\end{array}$} & \multicolumn{3}{|c|}{ Pore Volume (cc/g) } \\
\hline & & Acidic & Basic & & Micro & Meso & Macro \\
\hline BS & 5.59 & 0.050 & 0.605 & 0.265 & $\mathrm{~N} / \mathrm{A}^{*}$ & $\mathrm{~N} / \mathrm{A}^{*}$ & $\mathrm{~N} / \mathrm{A}^{*}$ \\
\hline BS500 & 9.85 & 0.006 & 0.127 & 0.937 & $\mathrm{~N} / \mathrm{A}^{*}$ & 0.004 & 0.006 \\
\hline BS1000 & 0.006 & 0.006 & 0.187 & 0.187 & $\mathrm{~N} / \mathrm{A}^{*}$ & 0.019 & 0.005 \\
\hline
\end{tabular}

\subsection{Adsorption Capability of Sr(II) And Cs(I)}

The quantities of Sr(II) and Cs(I) adsorbed onto BS, BS500, and BS1000 are shown in Figure 2. The amount of $\operatorname{Sr}(\mathrm{II})$ adsorbed was not affected by the calcination treatment. Conversely, the amount of $\mathrm{Cs}(\mathrm{I})$ adsorbed decreased with increasing calcination temperatures. These results suggest that the adsorption mechanisms of Sr(II) and Cs(I) were different for the virgin BS and calcined BS.

Moreover, the amount of Sr(II) adsorbed was greater than that of the Cs(I) adsorbed. The crystal radius and ionic radius of $\operatorname{Sr}(1.32-1.58 \AA$ and $1.18-1.44 \AA$ ) were both smaller than those of Cs

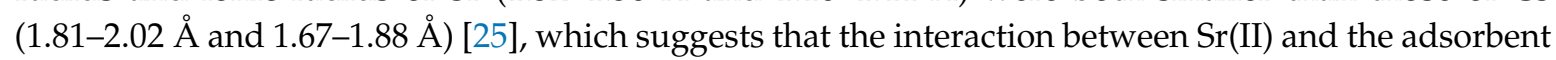
easily occurred compared to $\mathrm{Cs}(\mathrm{I})$ in the aqueous solution. In addition, these properties might affect the solvation of hydroxyl ions (solvent effect) under our experimental conditions. A comparison of the $\mathrm{Sr}(\mathrm{II})$ and $\mathrm{Cs}(\mathrm{I})$ adsorption capability of BS with other adsorbents is listed in Table 3 [10,26-30]. The BS 
exhibited good potential to be used for $\mathrm{Sr}(\mathrm{II})$ and $\mathrm{Cs}(\mathrm{I})$ removal from the aqueous solution comparable to other reported adsorbents (except for brewery waste biomass, Rhizopus nigricans, arca shell biomass, and Gracilaria corticata). The obtained results indicated that the initial concentration of $\mathrm{Sr}(\mathrm{II})$ or $\mathrm{Cs}(\mathrm{I})$ is important for ion removal from the aqueous solution. Therefore, this study evaluated the effect of the initial concentration on the adsorption (adsorption isotherms), as discussed in Section 3.4.

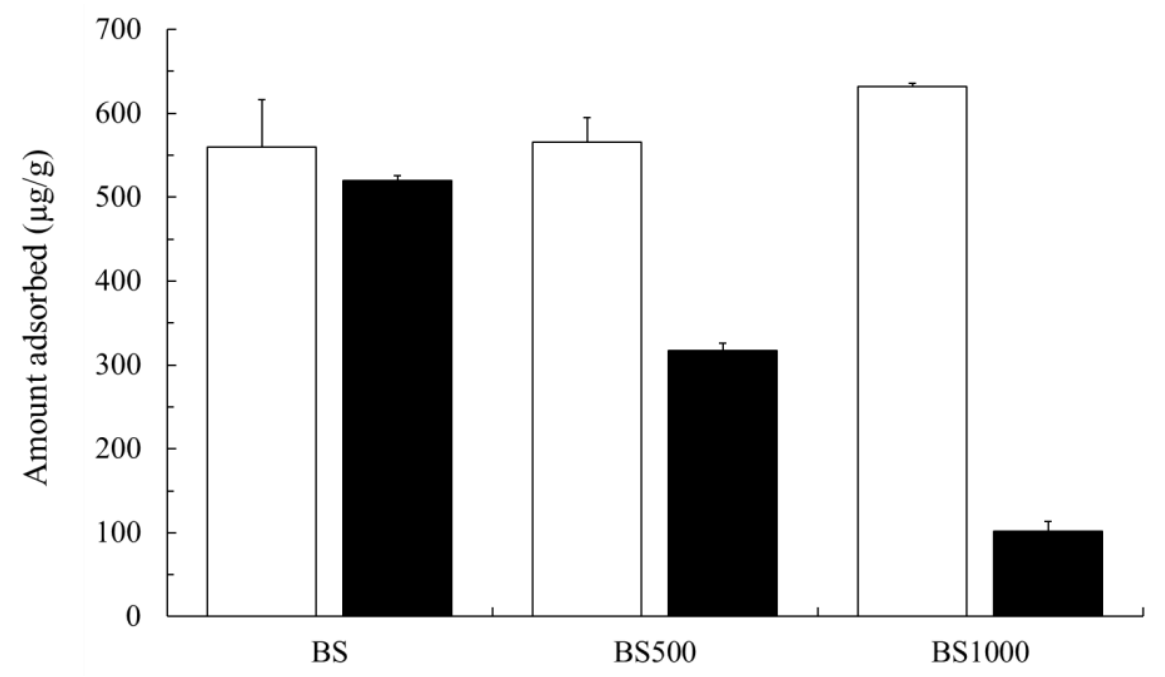

Figure 2. Amounts adsorbed of $\mathrm{Sr}(\mathrm{II})$ and $\mathrm{Cs}(\mathrm{I})$ onto adsorbents. Initial concentration: $1000 \mu \mathrm{g} / \mathrm{L}$, sample volume: $50 \mathrm{~mL}$, adsorbent: $0.05 \mathrm{~g}$, temperature: $25^{\circ} \mathrm{C}$, contact time: $24 \mathrm{~h}, 100 \mathrm{rpm}, \square: \operatorname{Sr}(\mathrm{II})$, ш: $\operatorname{Cs}(\mathrm{I})$.

Table 3. Comparison of Sr(II) or Cs(I) adsorption capacity of BS with other reported adsorbents.

\begin{tabular}{|c|c|c|c|c|c|c|c|c|}
\hline Samples & Adsorbents & $\begin{array}{c}\text { Adsorption } \\
\text { Capability } \\
\text { (mg/g) }\end{array}$ & $\mathrm{pH}$ & Temp. $\left({ }^{\circ} \mathrm{C}\right)$ & $\begin{array}{c}\text { Initial } \\
\text { Concentration } \\
(\mathrm{mg} / \mathrm{L})\end{array}$ & $\begin{array}{l}\text { Contact } \\
\text { Time (h) }\end{array}$ & $\begin{array}{l}\text { Adsorbent } \\
\text { (g/L) }\end{array}$ & Ref. \\
\hline \multirow{6}{*}{$\operatorname{Sr}(\mathrm{II})$} & $\begin{array}{l}\text { Paprika } \\
\text { biochar }\end{array}$ & 0.02 & - & 25 & 1 & 24 & 1 & [26] \\
\hline & $\begin{array}{c}\text { Spent } \\
\text { mushroom } \\
\text { biochar }\end{array}$ & 0.04 & - & 25 & 1 & 24 & 1 & [26] \\
\hline & $\begin{array}{c}\text { Rice straw } \\
\text { biochar }\end{array}$ & 0.05 & - & 25 & 1 & 24 & 1 & [26] \\
\hline & $\begin{array}{l}\text { Brewery's } \\
\text { waste } \\
\text { biomass }\end{array}$ & 7.91 & 4 & 30 & $\begin{array}{l}\text { Approximately } \\
700\end{array}$ & 3 & 2 & [10] \\
\hline & $\begin{array}{l}\text { Rhizopus } \\
\text { nigricans }\end{array}$ & 24.5 & 5 & $22 \pm 1$ & 1000 & 2 & - & [27] \\
\hline & BS & 0.63 & - & 25 & 1 & 24 & 1 & $\begin{array}{l}\text { This } \\
\text { study }\end{array}$ \\
\hline \multirow{5}{*}{$\mathrm{Cs}(\mathrm{I})$} & $\begin{array}{l}\text { Brewery's } \\
\text { waste } \\
\text { biomass }\end{array}$ & 10.1 & 4 & 30 & $\begin{array}{l}\text { Approximately } \\
700\end{array}$ & 3 & 2 & [10] \\
\hline & $\begin{array}{l}\text { Arca shell } \\
\text { biomass }\end{array}$ & 4.00 & 5.5 & $25 \pm 2$ & $10-500$ & 3 & 5 & [29] \\
\hline & $\begin{array}{l}\text { Bamboo } \\
\text { charcoal }\end{array}$ & 0.17 & - & 20 & 800 & 6 & 1 & [28] \\
\hline & $\begin{array}{c}\text { Gracilaria } \\
\text { corticata }\end{array}$ & 14.6 & 5.5 & 30 & $20-500$ & 3 & 2 & [30] \\
\hline & BS & 0.52 & - & 25 & 1 & 24 & 1 & $\begin{array}{l}\text { This } \\
\text { study }\end{array}$ \\
\hline
\end{tabular}


In addition, to find the adsorption mechanism, the relationship between the quantity of Sr(II) or $\mathrm{Cs}(\mathrm{I})$ adsorbed and the properties of the adsorbents (Table 2) were evaluated. The correlation coefficients $\left(r^{2}\right)$ between the amount of $\mathrm{Sr}(\mathrm{II})$ adsorbed and the $\mathrm{pH}_{\mathrm{pzc}}$, acidic functional groups, basic functional groups, and specific surface area were 0.527 (positive), 0.312 (negative), 0.211 (negative), and 0.996 (positive), respectively. Moreover, the correlation coefficients $\left(r^{2}\right)$ between the amount of Cs(I) adsorbed and the described properties were 0.899 (negative), 0734 (positive), 0.626 (positive), and 0.772 (negative), respectively. The adsorbent surface properties $\left(\mathrm{pH}_{\mathrm{pzc}}\right.$ and specific surface area) affected the adsorption capability of $\mathrm{Sr}$ (II) and Cs(I) from the aqueous solution. Therefore, the elemental distribution of $\mathrm{Sr}$ or Cs onto the BS surface before and after adsorption was investigated (Figure 3), and the involvement of other factors was evaluated, as described in Section 3.5. The results from Figure 3 demonstrated that $\mathrm{Sr}$ and $\mathrm{Cs}$ were detected after adsorption, indicating that the interaction between $\mathrm{Sr}(\mathrm{II})$ or $\mathrm{Cs}(\mathrm{I})$ and the BS surface occurred under our experimental conditions.

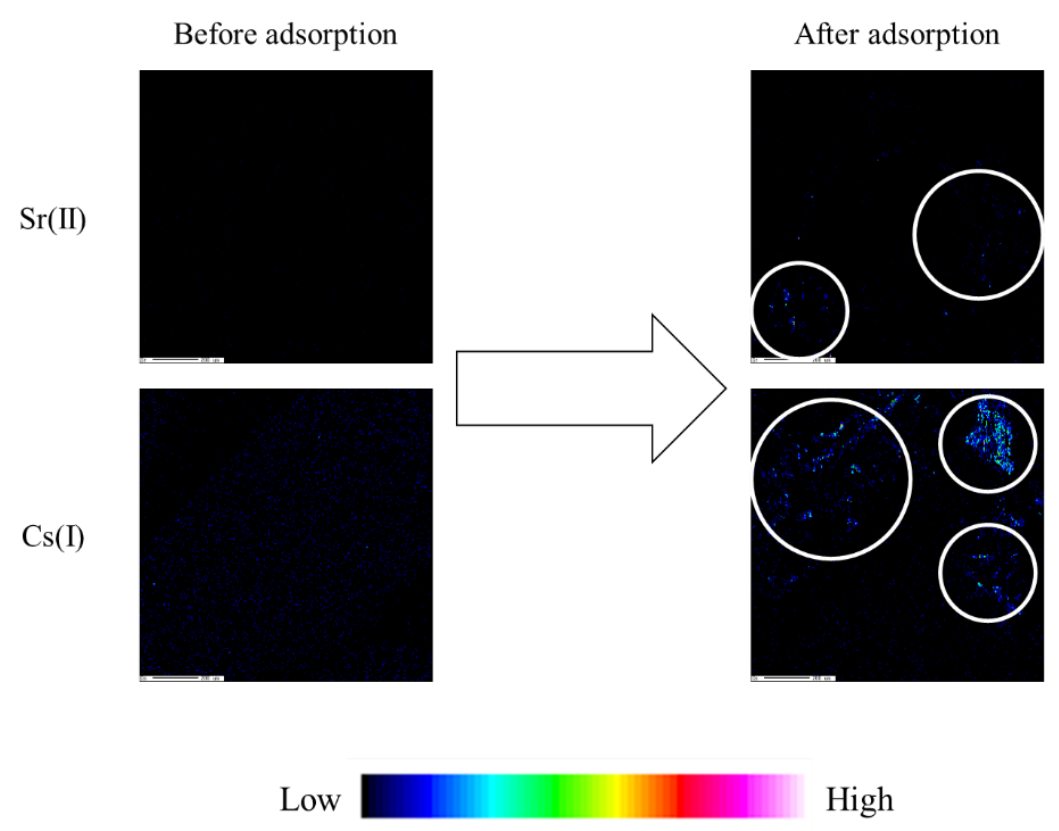

Figure 3. Qualitative analysis of BS surface before and after adsorption of $\mathrm{Sr}(\mathrm{II})$ and $\mathrm{Cs}(\mathrm{I})$.

\subsection{Adsorption Kinetics of Sr(II) And Cs(I)}

Figure 4 shows the kinetics data of $\mathrm{Sr}(\mathrm{II})$ and $\mathrm{Cs}(\mathrm{I})$ adsorption. The adsorption equilibrium of $\mathrm{Sr}(\mathrm{II})$ and $\mathrm{Cs}(\mathrm{I})$ onto the BS was reached at approximately $6 \mathrm{~h}$ and $1 \mathrm{~h}$, respectively. Numerous studies reported previously that the adsorption equilibrium of $\operatorname{Sr}(\mathrm{II})$ and $\mathrm{Cs}(\mathrm{I})$ was $2 \mathrm{~h}, 3 \mathrm{~h}$, and $24 \mathrm{~h}$ using rice straw-based biochar beads, brewer waste biomass, and BTP300 [10,15,26] and $30 \mathrm{~min}, 8 \mathrm{~h}$, and $1 \mathrm{~h}$ using agriculture waste biomass, polyphenols enriched biomass-based adsorbent, and BTP300, respectively $[7,15,31]$. Therefore, BS could be a potential candidate adsorbent for $\mathrm{Sr}$ (II) and Cs(I) removal from an aqueous solution.

The obtained data were fitted to the pseudo-first order model and pseudo-second order model (Table 4). The adsorption kinetics of the metal ions in the liquid phase can be indicated in the pseudo-first order model (Equation (2)) or pseudo-second order model (Equation (3)) [32,33].

$$
\begin{aligned}
& \frac{d q_{t}}{d_{t}}=k_{1}\left(q_{e, \exp }-q_{t}\right), \\
& \frac{d q_{t}}{d_{t}}=k_{2}\left(q_{e, \exp }-q_{t}\right)^{2},
\end{aligned}
$$


where $q_{e, \exp }$ and $q_{t}$ are the quantities of $\operatorname{Sr}(\mathrm{II})$ and $\mathrm{Cs}(\mathrm{I})$ adsorbed at equilibrium and at time $t(\mu \mathrm{g} / \mathrm{g})$, respectively; $k_{1}(1 / \mathrm{h})$ and $k_{2}(\mathrm{~g} / \mu \mathrm{g} / \mathrm{h})$ are rate constants of the pseudo-first order and pseudo-second order models, respectively. To confirm conformance, the experimental data should be applied to the linear formula of each model (Equations (4) and (5)) [32,33].

$$
\begin{gathered}
\ln \left(q_{e, \text { exp }}-q_{t}\right)=\ln q_{e, c a l}-k_{1} t, \\
\frac{t}{q_{t}}=\frac{t}{q_{e, c a l}}+\frac{1}{k_{2} \times q_{e, c a l}},
\end{gathered}
$$

where $q_{e, c a l}$ is the amount of $\operatorname{Sr}(\mathrm{II})$ and $\operatorname{Cs}(\mathrm{I})$ adsorbed in the calculation $(\mu \mathrm{g} / \mathrm{g})$. From Table 4, the correlation coefficients of the pseudo-second order model (Sr(II): 0.986-0.998, Cs(I): 0.970-1.000) were higher than those of the pseudo-first order model ( $\operatorname{Sr}(\mathrm{II}): 0.917-0.961, \operatorname{Cs}(\mathrm{I}): 0.050-0.459)$. Moreover, $q_{e, \text { exp }}$ was closer to $q_{e, \text { cal }}$ of the pseudo-second order model than that of the pseudo-first order model. Thus, the overall rate of the $\mathrm{Sr}(\mathrm{II})$ or $\mathrm{Cs}(\mathrm{I})$ adsorption is acceptably controlled by the chemisorption process, and the rate determining mechanism depends on the diffusion process [34,35].

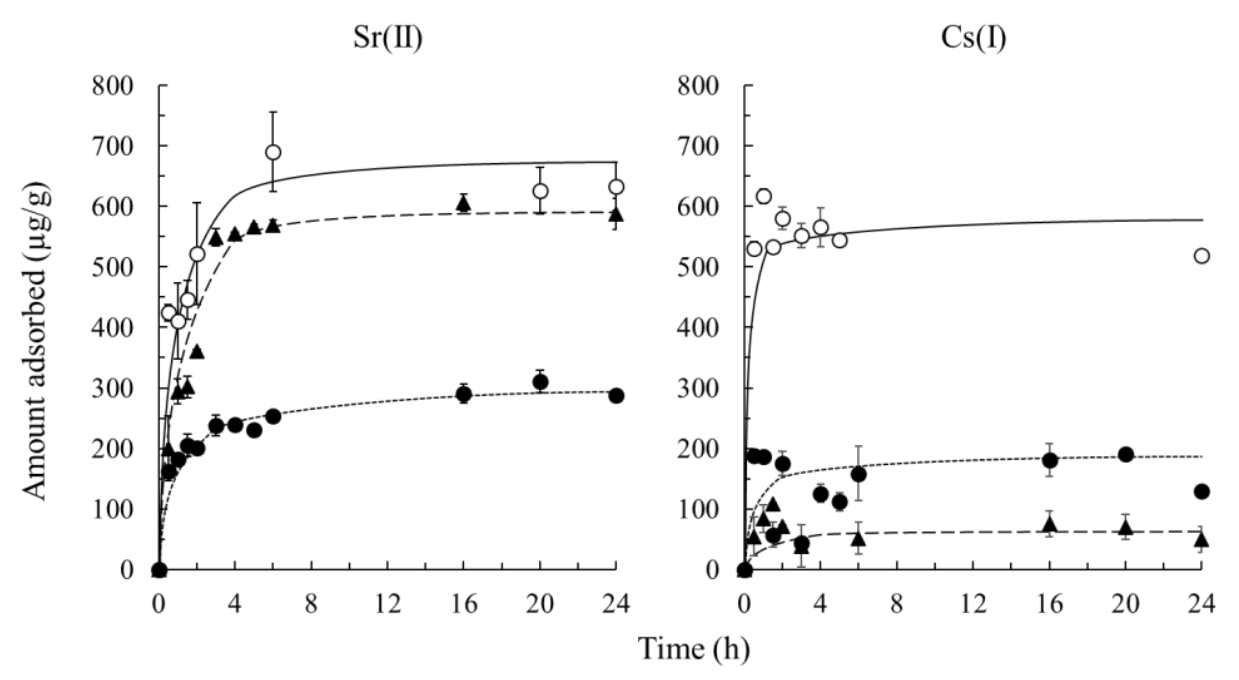

Figure 4. Adsorption kinetics of $\mathrm{Sr}(\mathrm{II})$ and $\mathrm{Cs}(\mathrm{I})$ onto adsorbents. Initial concentration: $1000 \mu \mathrm{g} / \mathrm{L}$, sample volume: $50 \mathrm{~mL}$, adsorbent: $0.05 \mathrm{~g}$, temperature: $25^{\circ} \mathrm{C}$, contact time: $10 \mathrm{~min}-24 \mathrm{~h}, 100 \mathrm{rpm}$, O: BS, •: BS500, $\mathbf{~ : ~ B S 1 0 0 0 . ~}$

Table 4. Fitting results of kinetic data using pseudo-first order model and pseudo-second order model.

\begin{tabular}{ccccccccc}
\hline \multirow{2}{*}{ Samples } & \multirow{2}{*}{ Adsorbents } & \multirow{2}{*}{$\boldsymbol{q}_{\boldsymbol{e}, \text { exp }}$} & \multicolumn{2}{c}{ Pseudo-First Order Model } & \multicolumn{2}{c}{ Pseudo-Second Order Model } \\
\cline { 3 - 8 } & & & $\boldsymbol{k}_{\mathbf{1}} \mathbf{( 1 / \mathbf { h } )}$ & $\boldsymbol{q}_{\boldsymbol{e}, \text { cal }}(\mathbf{m g} / \mathbf{g})$ & $\boldsymbol{r}$ & $\boldsymbol{k}_{\mathbf{2}}(\mathbf{g} / \mathbf{m g} / \mathbf{h})$ & $\boldsymbol{q}_{\boldsymbol{e}, \text { cal }}$ (mg/g) & $\boldsymbol{r}$ \\
\hline \multirow{3}{*}{ Sr(II) } & BS & 632.5 & $2.4 \times 10^{-1}$ & 293.0 & 0.961 & $1.2 \times 10^{-3}$ & 674.9 & 0.986 \\
& BS500 & 287.6 & $1.9 \times 10^{-1}$ & 114.8 & 0.917 & $4.1 \times 10^{-3}$ & 305.1 & 0.998 \\
& BS1000 & 587.3 & $6.4 \times 10^{-1}$ & 547.1 & 0.956 & $1.8 \times 10^{-3}$ & 621.9 & 0.998 \\
\hline \multirow{3}{*}{ Cs(I) } & BS & 519.4 & $4.8 \times 10^{-3}$ & 88.0 & 0.050 & $-2.4 \times 10^{-2}$ & 519.6 & 1.000 \\
& BS500 & 191.7 & $5.4 \times 10^{-2}$ & 10.9 & 0.459 & $-1.5 \times 10^{-2}$ & 151.8 & 0.972 \\
& BS1000 & 49.2 & $3.6 \times 10^{-3}$ & 47.0 & 0.090 & $-7.8 \times 10^{-2}$ & 58.3 & 0.970 \\
\hline
\end{tabular}

\subsection{Adsorption Isotherms of Sr(II) And Cs(I)}

Figure 5 shows the adsorption isotherms data of $\operatorname{Sr}(\mathrm{II})$ and Cs(I) with BS, BS500, and BS1000. The amount adsorbed was in the order BS500 < BS1000 < BS for Sr(II) and BS1000 $<$ BS500 < BS for $\mathrm{Cs}(\mathrm{I})$. To evaluate the adsorption mechanism, adsorption isotherms data were fitted to the Langmuir and Freundlich isotherm models (Table 5). 


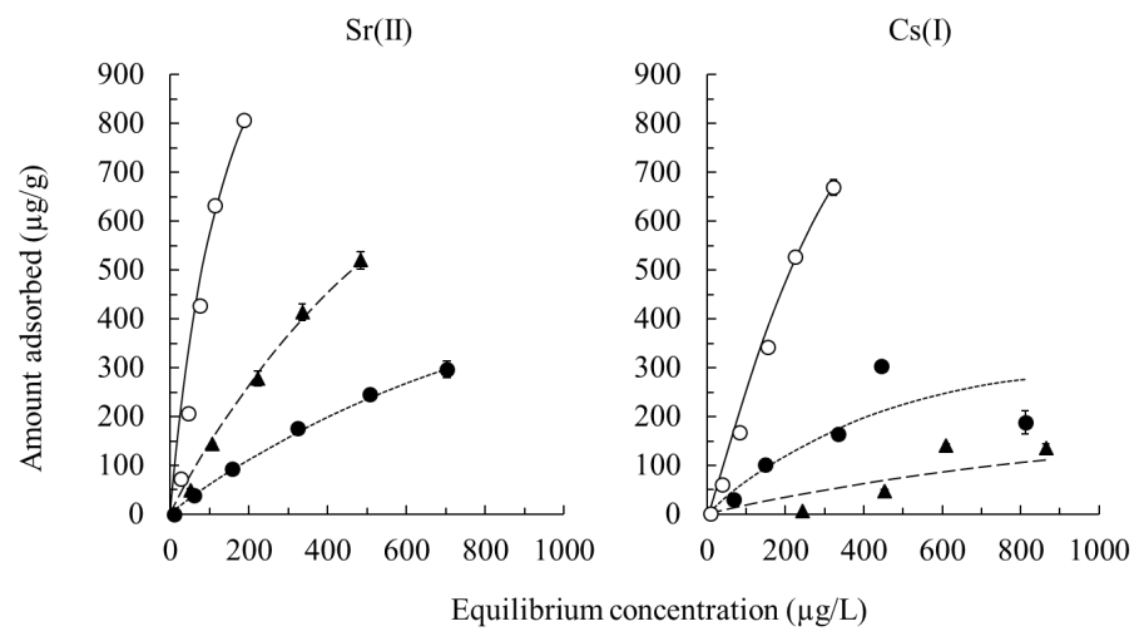

Figure 5. Adsorption isotherms of $\operatorname{Sr}(\mathrm{II})$ and $\mathrm{Cs}(\mathrm{I})$ onto adsorbents. Initial concentration: 1-1000 $\mu \mathrm{g} / \mathrm{L}$, sample volume: $50 \mathrm{~mL}$, adsorbent: $0.05 \mathrm{~g}$, temperature: $25^{\circ} \mathrm{C}$, contact time: $24 \mathrm{~h}, 100 \mathrm{rpm}, \bigcirc$ : BS,

•: BS500, ^: BS1000.

Table 5. Fitting results of isotherms data using Langmuir model and Freundlich model.

\begin{tabular}{cccccccc}
\hline \multirow{2}{*}{ Samples } & \multirow{2}{*}{ Adsorbents } & \multicolumn{3}{c}{ Langmuir Constants } & \multicolumn{3}{c}{ Freundlich Constants } \\
\cline { 3 - 7 } & & $\boldsymbol{q}_{\max }(\mathbf{m g} / \mathbf{g})$ & $\boldsymbol{K}_{\boldsymbol{L}}(\mathrm{L} / \mathbf{m g})$ & $\boldsymbol{r}$ & $\log \boldsymbol{K}_{\boldsymbol{F}}$ & $\mathbf{1 / n}$ & $\boldsymbol{r}$ \\
\hline \multirow{3}{*}{ Sr(II) } & BS & 441.6 & $5.6 \times 10^{-3}$ & 0.962 & 1.3 & 1.5 & 0.966 \\
& $\mathrm{BS} 500$ & 838.4 & $8.0 \times 10^{-4}$ & 1.000 & 0.8 & 1.3 & 0.998 \\
& $\mathrm{BS} 1000$ & 825.0 & $1.1 \times 10^{-3}$ & 0.989 & 1.1 & 0.9 & 0.990 \\
\hline \multirow{3}{*}{$\mathrm{Cs}(\mathrm{I})$} & BS & 948.0 & $1.6 \times 10^{-3}$ & 0.996 & 1.1 & 1.1 & 0.997 \\
& BS500 & 421.0 & $1.0 \times 10^{-3}$ & 0.986 & 1.1 & 0.3 & 0.981 \\
& BS1000 & 12.1 & $1.4 \times 10^{-3}$ & 0.964 & 2.6 & $3.7 \times 10^{-6}$ & 0.957 \\
\hline
\end{tabular}

The Langmuir isotherm formula can be represented by Equations (6) and (7) [34,35]:

$$
\begin{gathered}
q=\frac{K_{L} q_{\max } C}{1+K_{L} C} \\
\frac{1}{q}=\frac{1}{q_{\max }}+\frac{1}{K_{L} q_{\max } C}
\end{gathered}
$$

where $q$ is the quantity of $\mathrm{Sr}(\mathrm{II})$ or $\mathrm{Cs}(\mathrm{I})$ adsorbed, $(\mu \mathrm{g} / \mathrm{g}), q_{\mathrm{max}}$ is the maximum amount of $\mathrm{Sr}(\mathrm{II})$ or $\mathrm{Cs}(\mathrm{I})$ adsorbed $(\mu \mathrm{g} / \mathrm{g}), K_{L}$ is the Langmuir isotherm constant $(\mathrm{L} / \mu \mathrm{g})$, and $C$ is the equilibrium concentration $(\mu \mathrm{g} / \mathrm{L})$. The Langmuir isotherm model is the theoretical model and can explain the monolayer adsorption onto homogenous surfaces. In addition, this model is considered based on the adsorption sites.

The Freundlich isotherm formula can be represented by Equations (8) and (9) [36,37]:

$$
\begin{gathered}
q=K_{F} C^{1 / n}, \\
\log q=\frac{1}{n} \log C+\log K_{F}
\end{gathered}
$$

where $K_{F}$ and $1 / n$ are the Freundlich isotherm constants. The Freundlich isotherm model is an empirical model and can explain the monolayer adsorption onto heterogeneous surfaces. In general, the adsorption reaction in the aqueous phase fits this model. In the Freundlich isotherm model, the form of the isotherm curve depends on the value of $n$. Particularly, when the value of $1 / n$ is $0.1-0.5$, adsorption occurs easily, and when the value of $1 / n$ is over two, it is hard to adsorb [38]. 
The fitting results of the isotherms data using the Langmuir model and Freundlich model area are illustrated in Table 5. The correlation coefficients of the Langmuir model (Sr(II): 0.962-1.000, Cs(I): 0.964-0.996) and Freundlich model (Sr(II): 0.966-0998, Cs(I): 0.957-0.997) were high. Thus, the $\operatorname{Sr}(\mathrm{II})$ or $\mathrm{Cs}(\mathrm{I})$ adsorption using BS is attributed to monolayer adsorption. In addition, the value of $1 / n(\mathrm{Sr}(\mathrm{II})$ : 0.8-1.3, Cs(I): 1.1-2.6) indicated that $\operatorname{Sr}(\mathrm{II})$ and $\mathrm{Cs}(\mathrm{I})$ were efficiently adsorbed onto the BS under our experimental conditions, and showed exceptional adsorption of Cs(I) using BS1000.

\subsection{Effect of $\mathrm{pH}$ on the Adsorption of $\mathrm{Sr}(\mathrm{II})$ And $\mathrm{Cs}(\mathrm{I})$}

The amount of $\operatorname{Sr}(\mathrm{II})$ and $\mathrm{Cs}(\mathrm{I})$ adsorbed in various $\mathrm{pH}$ conditions is shown in Figure 6. The solution $\mathrm{pH}$ affected the capability of $\mathrm{Sr}(\mathrm{II})$ and $\mathrm{Cs}(\mathrm{I})$ adsorption from the aqueous solution using the BS. Numerous studies previously reported the adsorption mechanisms of $\mathrm{Sr}(\mathrm{II})$ and $\mathrm{Cs}(\mathrm{I})$ using agricultural waste biomass or banana fiber adsorbent $[3,11,31]$, and explained that cationic ions were adsorbed according to the cation exchanges with the functional groups onto the biomass surface. Therefore, competition between $\mathrm{Sr}(\mathrm{II})$ or $\mathrm{Cs}(\mathrm{I})$ and $\mathrm{H}^{+}$(proton) occurred, and the adsorption capability decreased in acidic conditions (pH: 2-3). Conversely, the level of $\mathrm{Sr}(\mathrm{II})$ and $\mathrm{Cs}(\mathrm{I})$ adsorbed increased in weakly acidic conditions $(\mathrm{pH}>4.0)$; because the concentration of hydroxyl groups in the solution increased, the consumption of protons by competition adsorption onto the active site of the adsorbent also decreased. Similar trends occurred in this study (Figure 7).

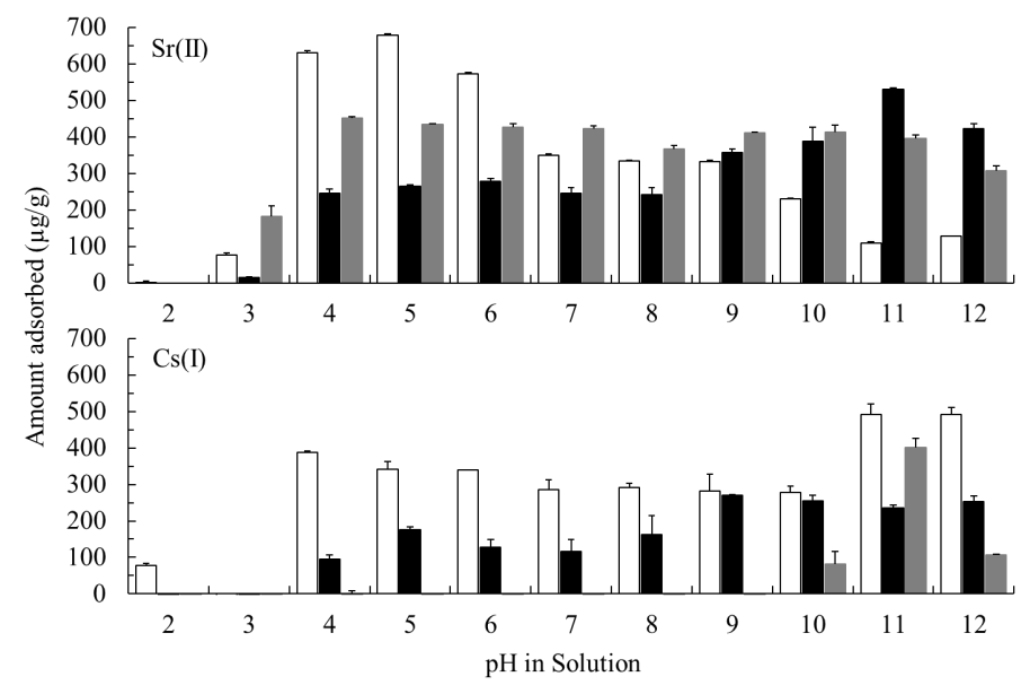

Figure 6. Amount of $\mathrm{Sr}(\mathrm{II})$ or $\mathrm{Cs}(\mathrm{I})$ adsorbed at different $\mathrm{pH}$ conditions. Initial concentration: $1000 \mu \mathrm{g} / \mathrm{L}$, sample volume: $50 \mathrm{~mL}$, adsorbent: $0.05 \mathrm{~g}$, temperature: $25^{\circ} \mathrm{C}$, contact time: $24 \mathrm{~h}, \mathrm{pH}$ in solution: $2-10$, $100 \mathrm{rpm}, \square:$ BS, $\mathbf{\square}:$ BS500, $\square:$ BS1000.

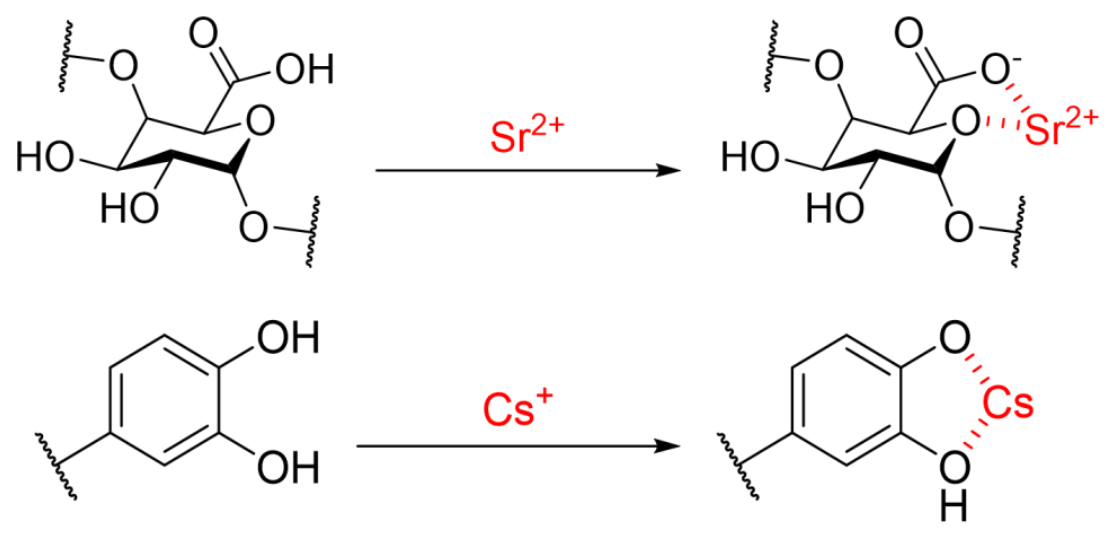

Figure 7. Adsorption mechanism of $\operatorname{Sr}(\mathrm{II})$ or $\mathrm{Cs}(\mathrm{I})$ by cellulose-hemicellulosic polysaccharide composite. 
Moreover, lignins, or surface functional groups which contained a lone pair of electrons, present in oxygen affected the adsorption site of $\mathrm{Sr}(\mathrm{II})$ and $\mathrm{Cs}(\mathrm{I})$. Various studies reported previously that the adsorption site of $\mathrm{Sr}$ (II) could be considered a low acidity ion exchange reaction site, additional adsorption site, or mucilage polysaccharide (carboxyl groups, hydroxyl groups, etc.) in waste biomass $[3,7,11,31]$. There is a lack of information regarding the adsorption mechanism of Sr(II) and Cs(II) using BS. Therefore, to elucidate the adsorption mechanism of these cations, this study focused on the cellulosic hydrocolloid in BS.

Cellulosic hydrocolloid was produced from the BS in the aqueous phase, indicating that the BS adsorbs water. The hydrocolloids were present as a type of cellulose-hemicellulosic polysaccharide composite [19]. The cellulosic hydrocolloid of the BS contained approximately $43 \%$ glucomannan and approximately $24 \%(1,4)$-xylan. Therefore, to determine the relationship between cellulosic hydrocolloid and the adsorption capability, glucomannan and (1,4)-xylan were decomposed (hydrolyzed) by Mannanase BGM, pectinase G, hemicellulase, and cellulase A, respectively (denoted as M-BS, P-BS, H-BS, and C-BS). Figure 8 shows the SEM images of M-BS, P-BS, H-BS, and C-BS and the quantity of $\mathrm{Sr}(\mathrm{II})$ and $\mathrm{Cs}(\mathrm{I})$ adsorbed. The quantity of $\mathrm{Sr}(\mathrm{II})$ or $\mathrm{Cs}(\mathrm{I})$ adsorbed onto the BS was greater than that onto the BS treated with each enzyme, indicating that the cellulosic hydrocolloid containing glucomannan or $(1,4)$-xylan was related to the adsorption capability of Sr(II) and Cs(I) using BS (except for M-BS in Sr(II) adsorption). Moreover, glucomannan and (1,4)-xylan affected the adsorption capability of Cs(I) or $\mathrm{Sr}(\mathrm{II})$. Therefore, the obtained results are useful, demonstrating the removal of $\mathrm{Sr}$ (II) and $\mathrm{Cs}(\mathrm{I})$ using BS. However, the contribution of each factor (cellulosic hydrocolloid) was not elucidated for the removal of $\operatorname{Sr}(\mathrm{II})$ and $\mathrm{Cs}(\mathrm{I})$ from the aqueous phase in this study. Further studies are required to determine the adsorption mechanisms of Sr(II) and Cs(I) using BS or to improve their adsorption capability.

(a)

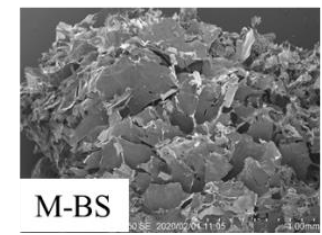

(b)

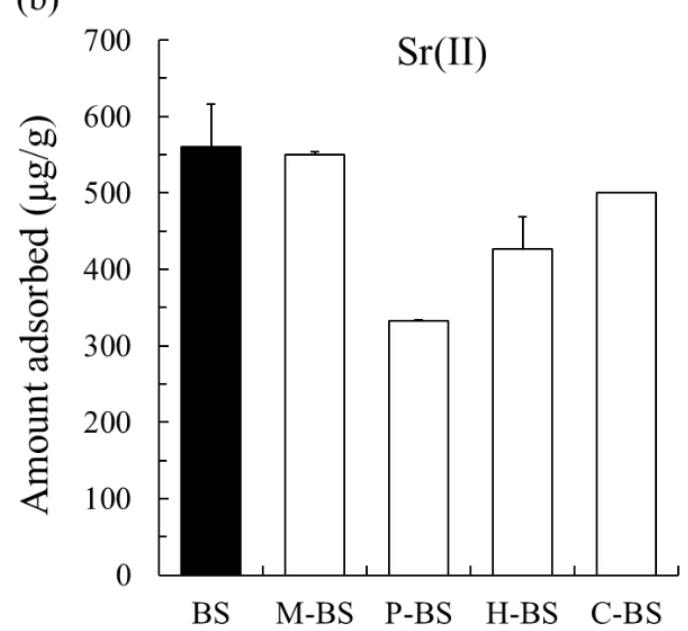

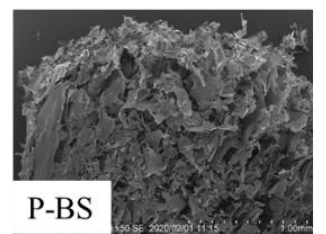
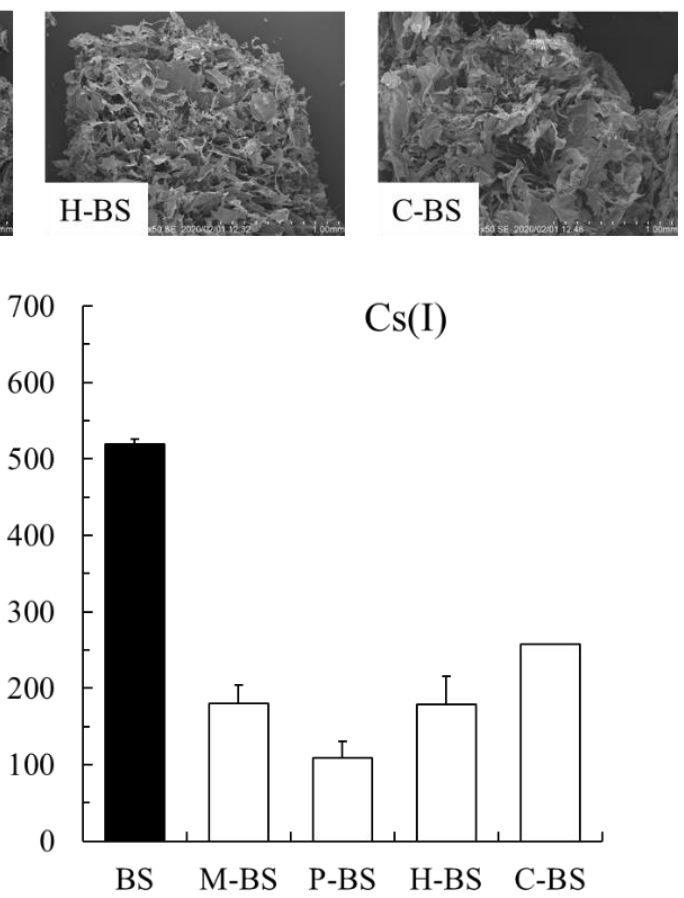

Figure 8. SEM images of adsorbents (a) and amount of $\mathrm{Sr}(\mathrm{II})$ and $\mathrm{Cs}(\mathrm{I})$ adsorbed onto enzyme-treated BSs (b). Initial concentration: $1000 \mu \mathrm{g} / \mathrm{L}$, sample volume: $50 \mathrm{~mL}$, adsorbent: $0.05 \mathrm{~g}$, temperature: $25^{\circ} \mathrm{C}$, contact time: $24 \mathrm{~h}, 100 \mathrm{rpm}$.

\section{Conclusions}

We prepared novel carbonaceous materials (BS500 and BS1000) produced from basil seed for the removal of Sr(II) and Cs(I) in the aqueous phase. The physicochemical characteristics of BS500 and BS1000 were drastically changed after calcination. The quantity of $\operatorname{Sr}(\mathrm{II})$ and Cs(I) adsorbed onto BS 
was greater than that of BS500 and BS1000, indicating that calcination of the BS did not improve the adsorption capability of these ions from the aqueous phase. The adsorbent surface properties $\left(\mathrm{pH}_{\mathrm{pzc}}\right.$ and specific surface area) were involved in the adsorption of $\mathrm{Sr}(\mathrm{II})$ and $\mathrm{Cs}(\mathrm{I})$ under our experimental condition. The adsorption kinetics followed the pseudo-second order model (the correlation coefficients of Sr(II) and Cs(I) were $0.986-0.998$ and $0.970-1.000$, respectively). The adsorption isotherm data fitted to the Langmuir and Freundlich models. The optimal $\mathrm{pH}$ condition for $\mathrm{Sr}(\mathrm{II})$ and $\mathrm{Cs}(\mathrm{I})$ removal was approximately over 4.0. Moreover, the quantity of Sr(II) and Cs(I) adsorbed onto M-BS, P-BS, H-BS, and C-BS was lower than that of BS. These results indicate that glucomannan and $(1,4)$-xylan in cellulosic hydrocolloid were related to the adsorption capability of the BS on $\mathrm{Cs}(\mathrm{I})$ or $\mathrm{Sr}$ (II) (except for M-BS in $\mathrm{Sr}(\mathrm{II})$ adsorption). Our study demonstrated that BS is useful and is a potential candidate for $\mathrm{Sr}(\mathrm{II})$ and $\mathrm{Cs}$ (I) removal from the aqueous phase, and elucidated some of the adsorption mechanisms of $\operatorname{Sr}$ (II) and $\mathrm{Cs}(\mathrm{II})$ from the aqueous phase.

Author Contributions: Conceptualization, N.K. and F.O.; investigation, Y.U., C.S., and T.N.; resources, C.S.; writing-original draft preparation, Y.U. and F.O.; writing-review and editing, F.O. and C.S.; project administration, N.K. All authors have read and agreed to the published version of the manuscript.

Funding: This research received no external funding.

Conflicts of Interest: The authors declare no conflict of interest.

\section{References}

1. Wang, J.L.; Zhuang, S.T.; Liu, Y. Metal hexacyanoferrates-based adsorbents for cesium removal. Coord. Chem. Rev. 2018, 374, 430-438. [CrossRef]

2. Manolopoulou, M.; Vagena, E.; Stoulos, S.; Ioannodou, A.; Papastefanou, C. Radioiodine and radiocesium in Thessaloniki, North Greece due to the Fukushima nuclear accident. J. Environ. Radioact. 2011, 102, 796-797. [CrossRef] [PubMed]

3. Chakraborty, D.; Maji, S.; Bandyopadhyay, A.; Basu, S. Biosorption of cesium-137 and strontium- 90 by mucilaginous seeds of Ocimum basilicum. Bioresour. Technol. 2007, 98, 2949-2952. [CrossRef] [PubMed]

4. Ahmadpour, A.; Zabihi, M.; Tahmasbi, M.; Bastami, T.R. Effect of adsorbents and chemical treatments on the removal of strontium from aqueous solution. J. Hazard. Mater. 2010, 182, 551-556. [CrossRef]

5. Martell, E.A. Atmospheric aspects of ${ }^{90} \mathrm{Sr}^{2+}$ fallout. Science 1959, 129, 1197-1206. [CrossRef] [PubMed]

6. Merceille, A.; Weinzaepfel, E.; Barre, Y.; Grandjean, A. The sorption behavior of synthetic sodium nonatitanate and Zeolite A for removing radioactive strontium from aqueous waste. Sep. Purif. Technol. 2012, 96, 81-88. [CrossRef]

7. Gurung, M.; Adhikari, B.B.; Alam, S.; Kawakita, H.; Ohto, K.; Inoue, K.; Harata, H. Adsorptive removal of Cs(I) from aqueous solution using polyphenols enriched biomass-based adsorbents. Chem. Eng. J. 2013, 231, 113-120. [CrossRef]

8. Yoo, J.I.; Shinagawa, T.; Wood, J.P.; Linak, W.P.; Santoianni, D.A.; King, C.J.; Seo, Y.C.; Wendt, J.O.L. High-temperature sorption of cesium and strontium on dispersed kaolinite powders. Environ. Sci. Technol. 2005, 39, 5087-5094. [CrossRef]

9. Liu, X.; Chen, G.R.; Lee, D.J.; Kawamoto, T.; Tanaka, H.; Chen, M.L.; Luo, Y.K. Adsorption removal of cesium from drinking waters: A mini review on use of biosorbents and other adsorbents. Bioresour. Technol. 2014, 160, 142-149. [CrossRef]

10. Chen, C.; Wang, J. Removal of $\mathrm{Pb}^{2+}, \mathrm{As}^{+}, \mathrm{Cs}^{+}$and $\mathrm{Sr}^{2+}$ from aqueous solution by brewery's waste biomass. J. Hazard. Mater. 2008, 151, 65-70. [CrossRef]

11. Kajiyama, T.; Kokusen, H. Study of adsorption behavior of cesium and strontium ions with banana fiber adsorbent. J. Ion Exchange 2016, 27, 8-12. [CrossRef]

12. He, Y.; Wang, J.; Shi, J. Sr(II) removal from aqueous solution by Bacillus cereus biomass, equilibrium and kinetic studies. Adv. Mater. Res. 2011, 230-232, 1129-1132. [CrossRef]

13. Zhu, T.; Wang, L.; Ge, F. Equilibrium and kinetic studies of aqueous cesium(I) ions biosorption by Pseudomonas alcaligenes biomass as a low-cost natural biosorbent. Adv. Mater. Res. 2011, 171, 53-56. [CrossRef] 
14. Ogata, F.; Nagai, N.; Soeda, A.; Yamashiro, K.; Nakamura, T.; Saenjum, C.; Kawasaki, N. Removal of Sr(II) ions from aqueous solution by human hair treated with EDTA. Bioresour. Technol. Rep. 2020, 9, 100393. [CrossRef]

15. Ogata, F.; Nagai, N.; Ueta, E.; Nakamura, T.; Kawasaki, N. Biomass potential of virgin and calcined tapioca (cassava starch) for the removal of Sr(II) and Cs(I) from aqueous solutions. Chem. Pharm. Bull. 2018, 66, 295-302. [CrossRef] [PubMed]

16. Sakdasri, W.; Ngamprasertsith, S.; Sooksai, S.; Noitang, S.; Sukaead, W.; Sawangkeaw, R. Defatted fiber produced from lemon Basil (Ocimum citriodorum Vis.) seed with supercritical $\mathrm{CO}_{2}$ : Economic analysis. Ind. Crops Pro. 2019, 135, 188-195. [CrossRef]

17. Naji-Tabasi, S.; Ali Razavi, S.M. Functional properties and applications of basil seed gum: An overview. Food Hydro. 2017, 73, 313-325. [CrossRef]

18. Choi, J.Y.; Heo, S.; Bae, S.; Kim, J.; Moon, K.D. Discriminating the origin of basil seeds (Ocimum basilicum L.) using hyperspectral imaging analysis. LWT 2020, 118, 108715. [CrossRef]

19. Azuma, J.; Sakamoto, M. Cellulosic hydrocolloid system present in seed of plants. Trends Glycosci. Glycotechnol. 2003, 15, 1-14. [CrossRef]

20. Melo, J.S.; D'Souza, S.F. Removal of chromium by mucilaginous seeds of Ocimum basilicum. Biorecour. Technol. 2004, 92, 151-155.

21. Faria, P.C.C.; Orfao, J.J.M.; Pereira, M.F.R. Adsorption of anionic and cationic dyes on activated carbons with different surface chemistries. Water Res. 2004, 38, 2043-2052. [CrossRef]

22. Boehm, H.P. Chemical identification of surface groups. J. Adv. Catal. Sci. Technol. 1966, 16, 179-274.

23. Yokoyama, R.; Hayashi, S.; Nakanishi, M.; Takada, J. $\mathrm{NO}_{3}-\mathrm{N}$ adsorption property of Ca-containing charcoal. J. Jpn. Soc. Water Environ. 2008, 31, 47-52. [CrossRef]

24. DzoyemL, J.P.; McGaw, J.; Kuete, V.; Bakowsky, U. Anti-inflammatory and Anti-nociceptive Activities of African Medicinal Spices and Vegetables. In Medicinal spices and vegetables from Africa: therapeutic potential against metabolic, inflammatory, infectious and systemic diseases; Academic Press: Amsterdam, The Netherlands, 2017; pp. 239-270.

25. Shannon, R.D. Revised effective ionic radii and systematic studies of interatomic distances in halides and chalcogenides. Acta Cryst. 1976, A32, 751-767. [CrossRef]

26. Jang, J.; Mirana, W.; Divine, S.D.; Nawaz, M.; Shahzad, A.; Woo, S.H.; Lee, D.S. Rice straw-based biochar beads for the removal of radioactive strontium from aqueous solution. Sci. Total Environ. 2018, 615, 698-707. [CrossRef] [PubMed]

27. Kogej, A.; Pavko, A. Comparison of Rhizopus nigricans in a pelleted growth from with some other types of waste microbial biomass as biosorbents for metal ions. World J. Microbiol. Biotechnol. 2001, 17, 677-685. [CrossRef]

28. Khandaker, S.; Kuba, T.; Kamida, S.; Uchikawa, Y. Adsorption of cesium from aqueous solution by raw and concentrated nitric acid-modified bamboo charcoal. J. Environ. Chem. Eng. 2017, 5, 1456-1464. [CrossRef]

29. Dahiya, S.; Tripathi, R.M.; Hedge, A.G. Biosorption of heavy metals and radionuclide from aqueous solutions by pre-treated arca shell biomass. J. Hazard. Mater. 2008, 150, 376-386. [CrossRef]

30. Jalali-Rad, R.; Ghafourian, H.; Asef, Y.; Dalir, S.T.; Sahafipour, M.H.; Gharanjik, B.M. Biosorption of cesium by native and chemically modified biomass of marine algal: introduce the new biosorbents for biotechnology applications. J. Hazard. Mater. 2004, B116, 125-134. [CrossRef]

31. Pangeni, B.; Paudyal, H.; Inoue, K.; Kawakita, H.; Ohto, K.; Gurung, M.; Alam, S. Development of low cost adsorbents from agricultural waste biomass for the removal of $\mathrm{Sr}(\mathrm{II})$ and $\mathrm{Cs}(\mathrm{I})$ from water. Waste Biomass Valor. 2014, 5, 1019-1028. [CrossRef]

32. Lagergren, S. Zur theorie der sogenannten adsorption geloster stoffie, Kunglia Svenska Vetenskapsakademiens. Handlingar 1898, 24, 1-39.

33. Ho, Y.S.; McKay, G. Pseudo-second order model for sorption process. Pro. Biochem. 1999, 34, 451-465. [CrossRef]

34. Chairat, M.; Rattanaphani, S.; Bremner, J.B.; Rattanaphani, V. An adsorption and kinetic study of lac dyeing on silk. Dyes Pigments 2005, 64, 231-241. [CrossRef]

35. Fang, Y.; Zhang, T.; Li, P.; Jiang, R.; Wu, S.; Nie, H.; Wang, Y. Phosphorus recovery from biogas fermentation liquid by Ca-Mg loaded biochar. J. Environ. Sci. 2015, 29, 106-114. [CrossRef] [PubMed] 
36. Langmuir, I. The constitution and fundamental properties of solids and liquids. J. Am. Chem. Soc. 1916, 38, 2221-2295. [CrossRef]

37. Freundlich, H.M.T. Over the adsorption in solution. J. Phy. Chem. 1906, 57, 385-471.

38. Abe, I.; Hayashi, K.; Kitagawa, M. Studies on the adsorption of surfactants on activated carbons. I. Adsorption of nonionic surfactants. Yukagaku 1976, 25, 145-150. 